\title{
MET Gene Amplification Negative
}

National Cancer Institute

\section{Source}

National Cancer Institute. MET Gene Amplification Negative. NCI Thesaurus. Code C160400.

An indication that amplification of the MET gene was not detected in a sample. 